\title{
Spontaneous subcapital femoral neck fracture complicating osteonecrosis of femoral head
}

\author{
Sumit Arora, Manoj Kumar, Yasim Khan, Nitish Bansal, Swati Gupta, Jatin Talwar, Vinod Kumar, Lalit Maini
}

From the Department of Orthopaedic Surgery, Maulana Azad Medical College \& associated Lok Nayak Hospital, New Delhi-110002, India

Spontaneous subcapital fracture (SSF) of femoral neck in pre-existent osteonecrosis of femoral head $(\mathrm{ONFH})$ is a rare presentation. Only a few cases have been reported so far and majority of them have been reported to have unilateral hip involvement.

We retrospectively reviewed clinical-radiological data of 10 patients (12 hips) with SSF complicating ONFH. All of them underwent uncemented total hip arthroplasty. All the available publications in the English language based medical literature were critically reviewed and results were summarized.

The median age of presentation was 32 years (range : 24 years to 61 years). They were followed up for a mean duration of 25 months (range : 12 months to 59 months). The most common risk factor was corticosteroid consumption ( 7 out of 10 patients). All except one (modified Ficat and Arlet stage II) belonged to advanced stage of ONFH \{stage III 3 patients (3 hips), stage IV 6 patients ( 8 hips)\}. The mean time lag of ONFH to presentation was 22.3 months (range : 5 months to 60 months), and SSF to presentation was 13.8 days (range : 1 day to 28 days). Mean preoperative Harris Hip Score was 10.8 (range : 8 to 14), which improved to 93 (range : 91 to 96 ) after total hip arthroplasty when last followed up $(p<0.05)$.

Corticosteroids induced ONFH has a propensity to develop SSF. This entity should find a place in existing classification system.

Keywords : Osteonecrosis of femoral head ; subcapital femoral neck fracture ; corticosteroid.

No benefits or funds were received in support of this study. None of the authors have a conflict of interest.

\section{INTRODUCTION}

Osteonecrosis of the femoral head (ONFH) is a disabling condition, which leads to progressive collapse of the femoral head. The possible risk

- Sumit Arora ${ }^{1}$ MS Ortho, DNB Ortho, MRCPS (Glasgow), MNAMS

- Manoj Kumar ${ }^{2}$ MS Ortho, DNB Ortho

- Yasim $\mathrm{Khan}^{3}$ MS Ortho, DNB Ortho

Nitish Bansal ${ }^{3}$ MS Ortho

- Swati Gupta ${ }^{4}$ MD Radiodiag, DNB Radiodiag, FRCR

- Jatin Talwar ${ }^{5}$ MS Ortho, MCh Ortho

- Vinod Kumar $^{2}$ MS Ortho, DNB Ortho

- Lalit Maini ${ }^{2}$ MS Ortho

${ }^{1}$ Associate Professor, Department of Orthopaedic Surgery, Maulana Azad Medical College \& associated Lok Nayak Hospital, New Delhi-110002.

${ }^{2}$ Director Professor, Department of Orthopaedic Surgery, Maulana Azad Medical College \& associated Lok Nayak Hospital, New Delhi-110002.

${ }^{3}$ Senior Resident, Department of Orthopaedic Surgery, Maulana Azad Medical College \& associated Lok Nayak Hospital, New Delhi-110002.

${ }^{4}$ Associate Professor, Department of Radiodiagnosis, Maulana Azad Medical College \& associated Lok Nayak Hospital, New Delhi-110002.

${ }^{5}$ Professor, Central Institute of Orthopaedics, Vardhman Mahavir Medical College \& associated Safdarjung Hospital, New Delhi-110029.

Correspondence : Dr. Sumit Arora, c/o Mr Raj Kumar Arora, B-253, Second floor, Derawal Nagar, Delhi-110009. Phone : +919868329389.

E-mail :mamc_309@yahoo.co.in

- 2021, Acta Orthopædica Belgica. 
factors include trauma, corticosteroid use, alcohol abuse, smoking, sickle cell anaemia, coagulation disorders, myeloproliferative disorders (Gaucher disease, leukaemia), decompression sickness, human immunodeficiency virus infection and anti-retro-viral therapy (1). The term 'idiopathic osteonecrosis' is used where a definitive cause cannot be identified. Radiographic findings in $\mathrm{ONFH}$ are lucency and subchondral sclerosis in early disease. As the disease progresses, these findings typically evolve into subchondral collapse, flattening of the femoral head, narrowing of the joint space and acetabular changes (2).

Spontaneous subcapital fracture (SSF) of femoral neck complicating ONFH is an uncommon presentation and only a few cases have been reported so far (3-15). These reports largely present unilateral subcapital SSF of the femoral neck, with femoral head in various stages of osteonecrosis (3-7,11-15).

We, hereby, present 10 patients (12 hips) of ONFH presenting with SSF of femoral neck. We also propose to make a separate subcategory in the existing Ficat and Arlet classification system (2) to include such, hitherto unclassified, presentation.

\section{PATIENTS AND METHODS}

We retrospectively reviewed the prospectively collected data of 10 patients (12 hips) of SSF of femoral neck in pre-existent ONFH who presented between January 2014-February 2019 to our hospital which is a tertiary care teaching referral hospital. Written, informed consent was obtained from all the patients authorising treatment, radiological and photographic documentation. They were also informed that data concerning the case might be submitted for publication and they consented. Institutional ethical clearance was obtained.

All the patients underwent radiographs. Additionally, MR scan was available for 6 patients whereas, NCCT hip was available for 5 patients. The patients were staged according to modified Ficat and Arlet classification (2) as follows : Early (0-II), Transition, and Late (III-IV) stages. Stage 0 represents pre-clinical and stage I pre-radiographic cases. Stage II displays diffuse porosis along with the areas of sclerosis and cystic changes. Transition stage shows crescentic line due to subchondral fracture and 'out of round' appearance due to segmental flattening of femoral head. Stage III shows characteristic sequestrum with collapse without reduction in joint space. Stage IV shows arthritis as joint space is reduced because of progressive collapse and loss of articular cartilage.

Pre-operative and post-operative functional assessment of hip was done using Harris Hip Score (HHS) (16). Grading of hip function using HHS was done as per Marchetti et al (17) : Poor $(<70)$; Fair (70-79) ; Good (80-89); Excellent (>90).

The case details have been summarized in Table I.

\section{RESULTS}

The median age of presentation was 32 years (range : 24 years to 61 years). Nine out of 10 patients were males. They were followed up for a mean duration of 25 months (range : 12 months to 59 months). The most common risk factor was corticosteroid consumption (7 out of 10 patients). Six out of these 7 patients were taking steroids on the advice of quacks/ chemist for improving appetite/ gaining muscle mass and were not on any other medications. Only 1 patient was on steroids for medical indications (for chronic eczema). All except one (modified Ficat and Arlet stage II) belonged to late stage of ONFH \{stage III 3 patients (3 hips), stage IV 6 patients $(8$ hips $)\}$. The mean time lag of ONFH to presentation was 22.3 months (range : 5 months to 60 months), and SSF to presentation was 13.8 days (range; 1 day to 28 days). None of the patients had history of trauma before developing SSF. Mean pre-operative Harris Hip Score was 10.8 (range : 8 to 14), which improved to 93 (range : 91 to 96) after total hip arthroplasty when last followed up $(p<0.05)$. None of the patients had infection or loosening of femoral/ acetabular components.

\section{DISCUSSION}

Regarding fracture terminology : There exists a diversity in description of this fracture that develops in the setting of extensive ONFH (3-15). A stress fracture may be defined as a complete or incomplete 


\begin{tabular}{|c|c|c|c|c|c|c|c|c|c|c|}
\hline 高 & 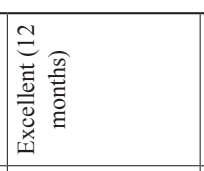 & 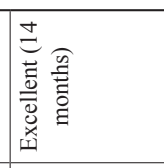 & 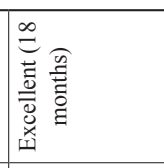 & 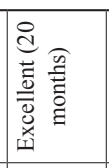 & 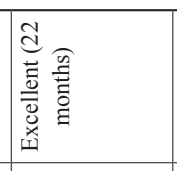 & 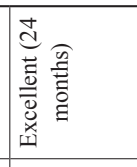 & 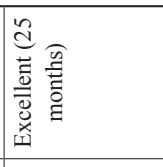 & 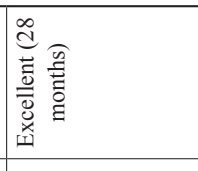 & 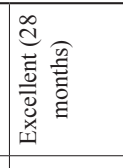 & 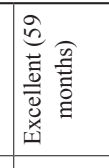 \\
\hline & 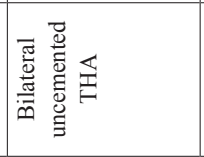 & 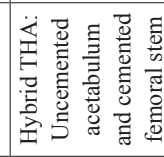 & 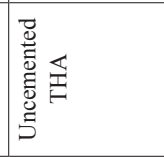 & 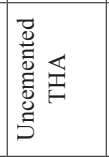 & 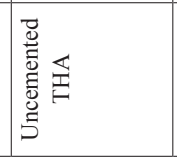 & 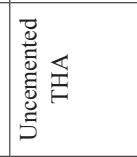 & 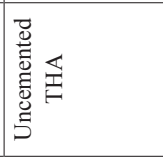 & 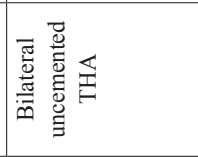 & 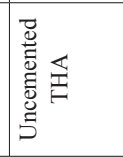 & 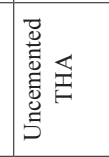 \\
\hline 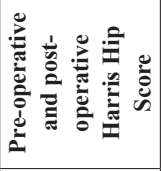 & $\infty \approx$ & 영 & $a 2$ & $=\bar{\sigma}$ & $\simeq \approx$ & $\pm ஃ$ & $\sigma \bar{\sigma}$ & $\simeq \bar{\sigma}$ & $\because 2$ & $\leadsto$ \\
\hline 先 & 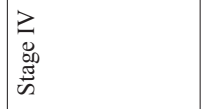 & 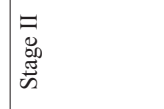 & 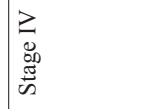 & 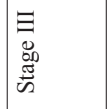 & 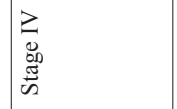 & 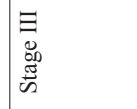 & 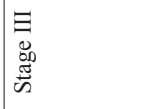 & 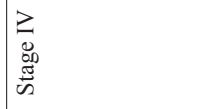 & 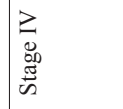 & 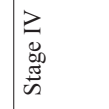 \\
\hline 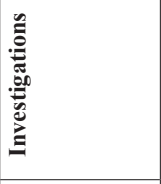 & 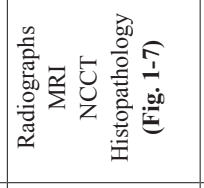 & 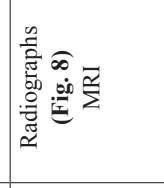 & 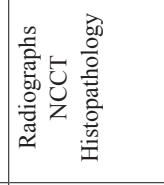 & 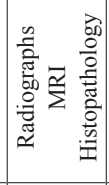 & $\begin{array}{ll}0 \\
0\end{array}$ & 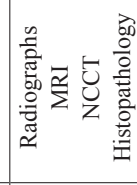 & 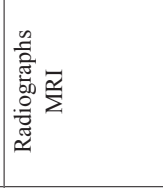 & 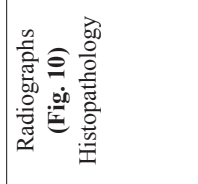 & 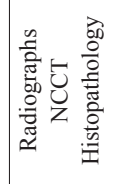 & 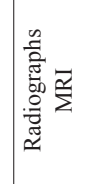 \\
\hline 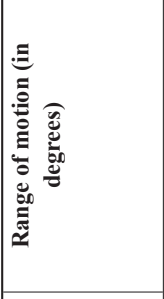 & 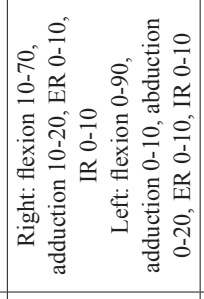 & 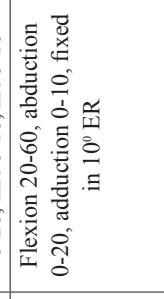 & 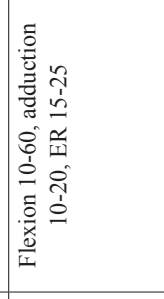 & 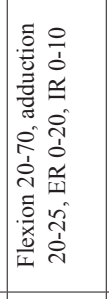 & 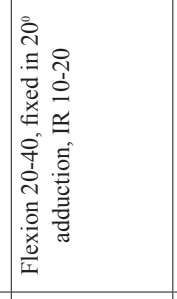 & 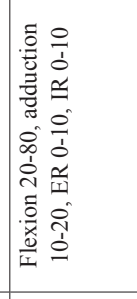 & 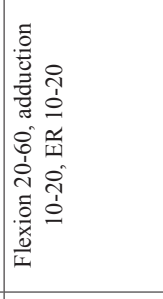 & 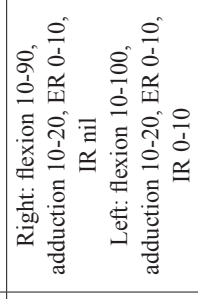 & 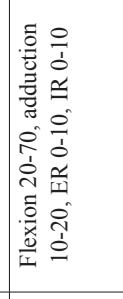 & 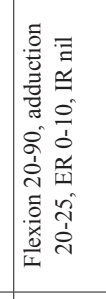 \\
\hline 题 & 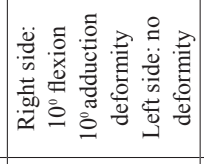 & 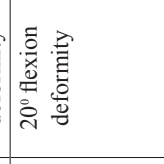 & 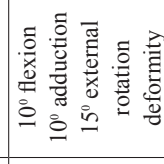 & 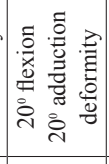 & 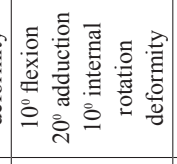 & 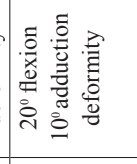 & 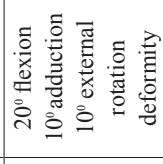 & 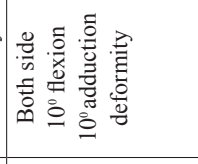 & 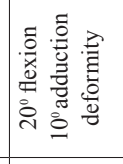 & 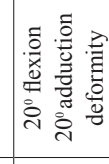 \\
\hline 产 & 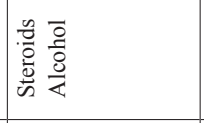 & 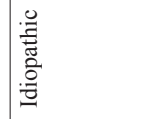 & 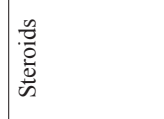 & 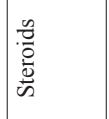 & 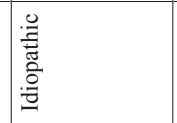 & : & 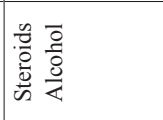 & 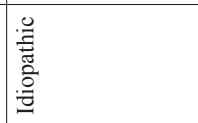 & 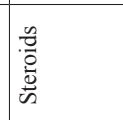 & 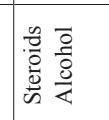 \\
\hline 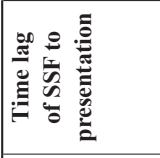 & 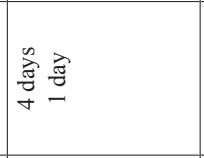 & $\begin{array}{l}\frac{y}{2} \\
\frac{y}{3} \\
m\end{array}$ & 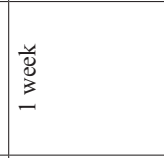 & 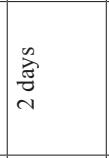 & 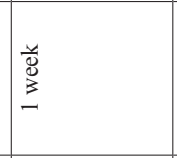 & $\begin{array}{l}\frac{n}{0} \\
\frac{\pi}{3} \\
3 \\
m\end{array}$ & 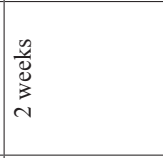 & 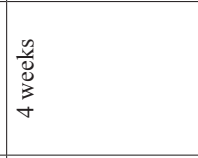 & $\begin{array}{l}\tilde{y} \\
\frac{\tilde{g}}{3} \\
\vdots \\
y\end{array}$ & 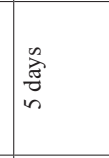 \\
\hline 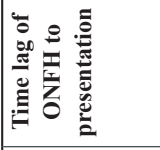 & 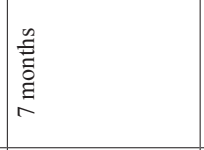 & 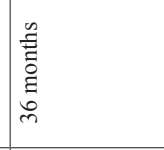 & 量 & 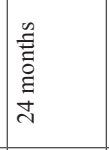 & 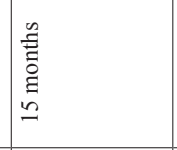 & 号 & $\begin{array}{l}n \\
\tilde{E} \\
\vdots \\
\vdots \\
\infty \\
-\end{array}$ & 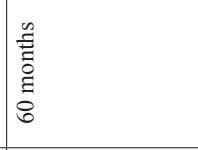 & 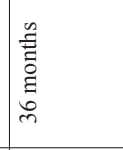 & 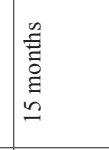 \\
\hline 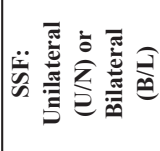 & 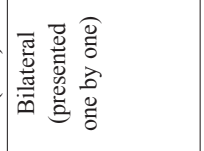 & 苛 & $\frac{\overrightarrow{.}}{.00}$ & 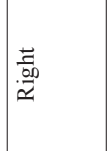 & 总 & 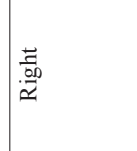 & 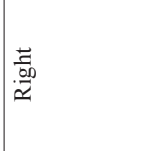 & 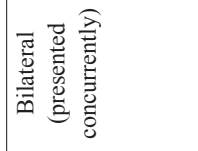 & 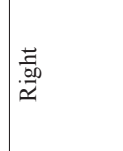 & 离 \\
\hline & 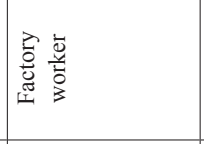 & 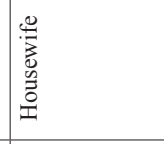 & 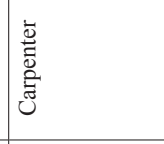 & 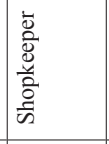 & 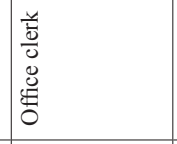 & 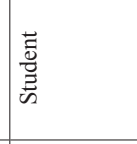 & 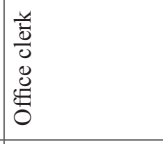 & 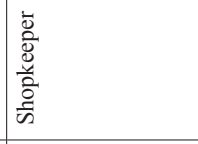 & 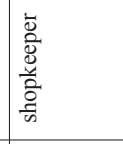 & 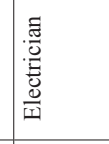 \\
\hline 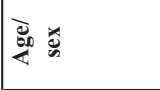 & 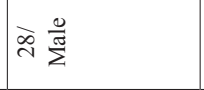 & 居 & ন & ल $\frac{0}{\pi}$ & $\Rightarrow \frac{0}{m}$ & 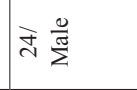 & 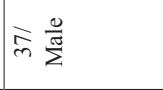 & 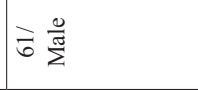 & $\infty_{m}^{\infty} \frac{0}{\pi}$ & ஓे $\frac{0}{\pi}$ \\
\hline$\dot{\dot{z}}$ & - & 4 & $\mathrm{~m}$ & a & in & 0 & r & $\infty$ & a & $\varrho$ \\
\hline
\end{tabular}




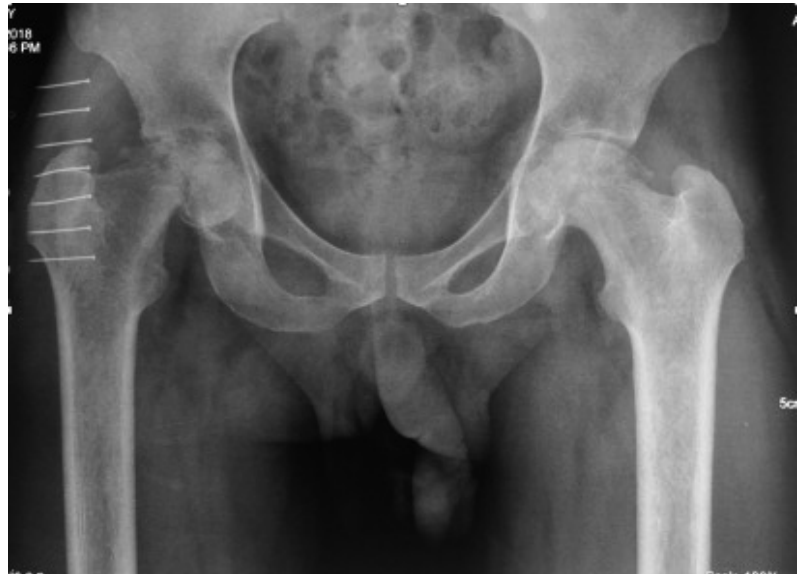

Figure 1. - Antero-posterior radiograph of pelvis with both hips showing deformation and subchondral sclerosis with areas of lysis in the right femoral head and flattening of weight bearing portion of left femoral head with osteophytes (modified Ficat and Arlet stage IV). SSF is clearly seen on the right side.

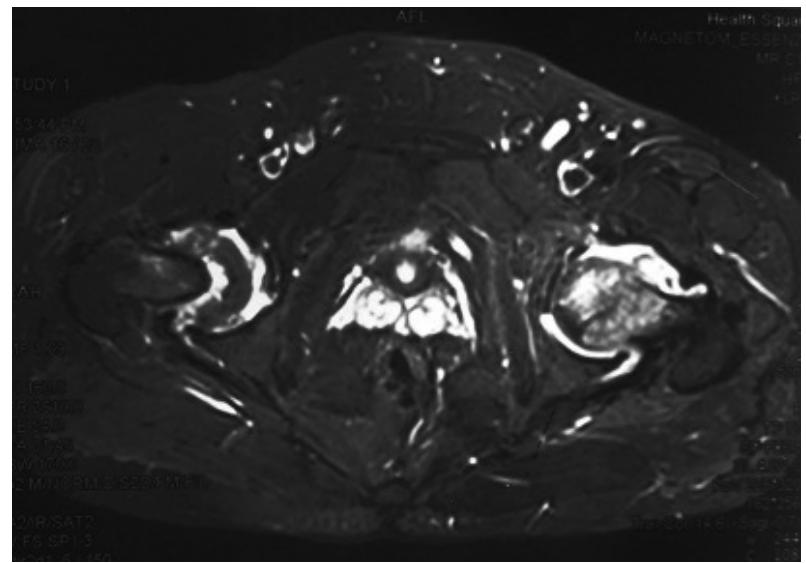

Figure 2. - Axial STIR image showing areas of altered signal intensity suggestive of extensive marrow edema with ONFH involving the bilateral femoral head and right femoral neck with deformed femoral head and reduced hip joint space seen with SSF.

fracture when subthreshold quantum of stress is applied in a rhythmical and repeated manner (18). The stress fracture may be classified into 3 types: Fatigue; Insufficiency; and Pathological type $(18,19)$. A fatigue type of stress fracture is the one which occurs in normal bones which are subjected to greater than normal stress and is classically seen during vigorous training of unaccustomed military recruits and athletes. Insufficiency or spontaneous stress fracture occurs when a bone with deficient
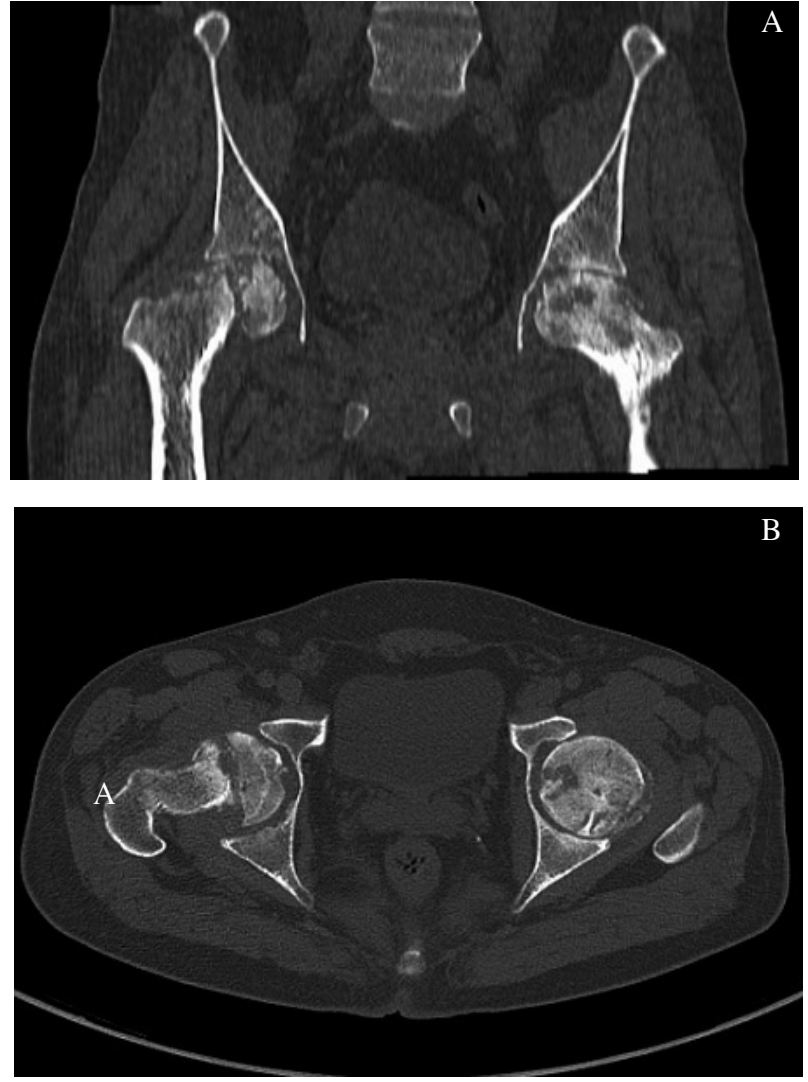

Figure 3. - (A) Coronal view, (B) Axial view NCCT of both hips showing evidence of ONFH on both the sides with SSF on the right side.

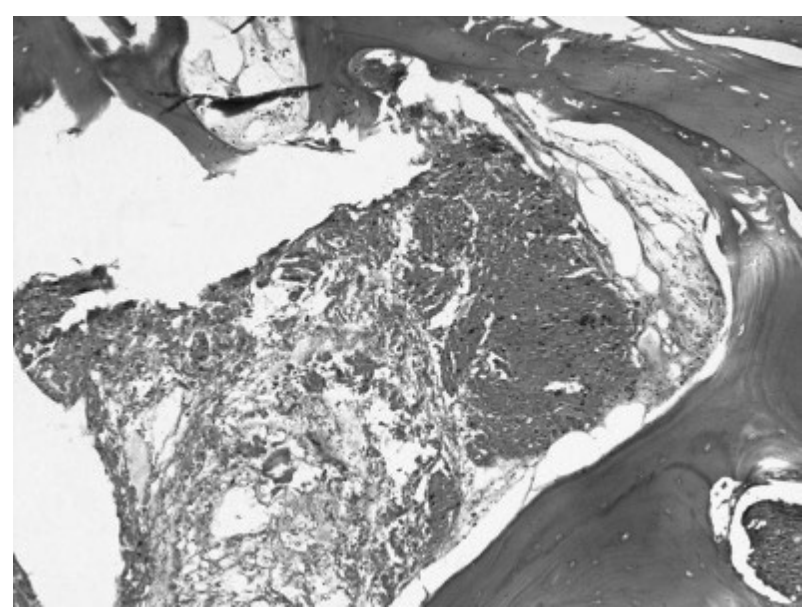

Figure 4. - Photomicrograph showing areas of necrosis and foci of calcification with an interim of fibroblastic proliferation along with viable bony trabeculae. There is associated presence of marrow fat necrosis (Haematoxylin \& Eosin ; 100x). 


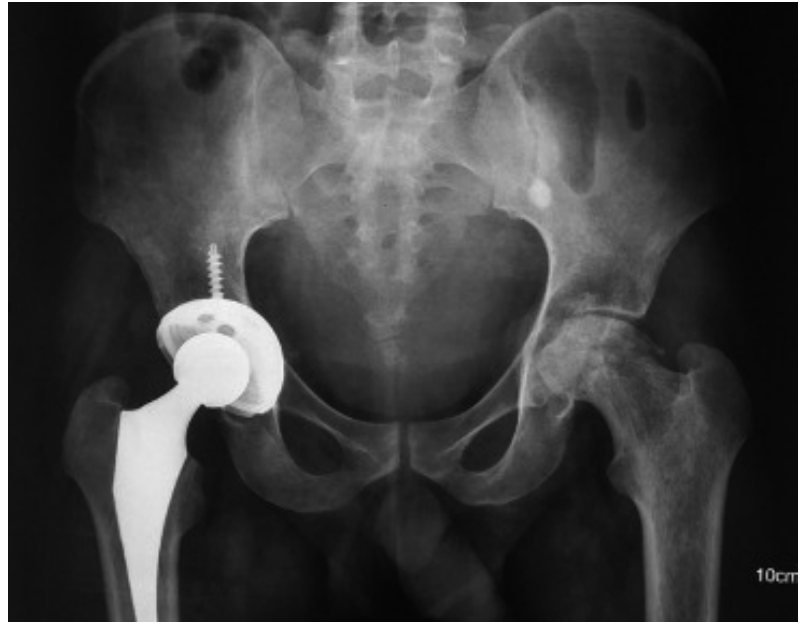

Figure 5. - Antero-posterior radiograph of pelvis with both hips obtained 3 weeks after right side THA showing evidence of SSF on the left side in the background of ONFH.

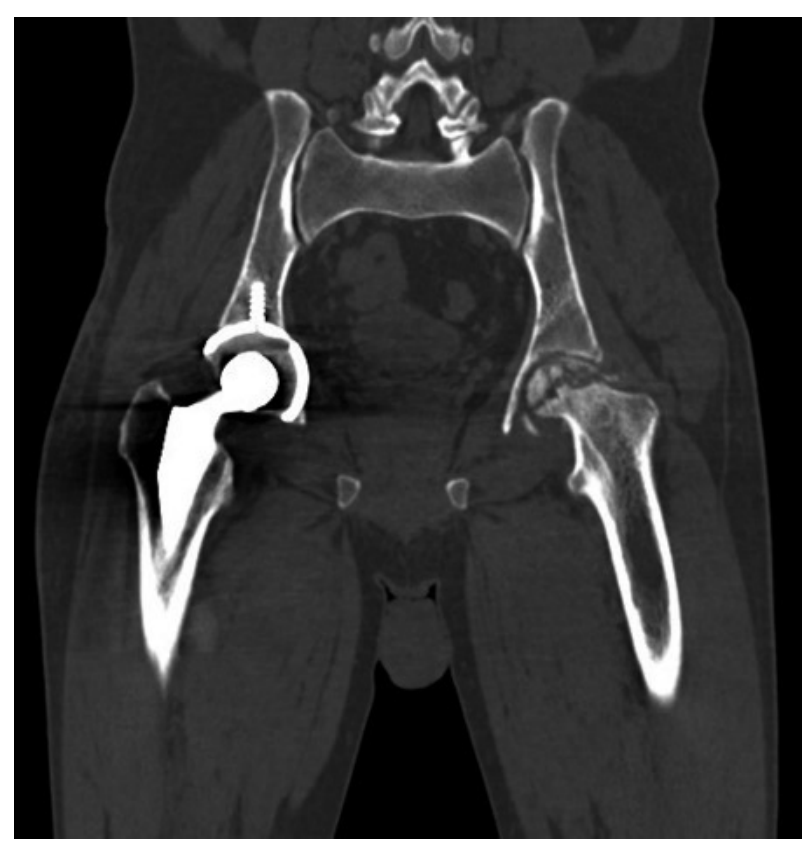

Figure 6. - Coronal view NCCT of both hips obtained 3 weeks after right side THA showing ONFH with evidence of SSF on the left side.

elastic resistance is subjected to physiological stress. The term pathological fracture is considered when a fracture happens in the setting of neoplastic etiology. For the descriptive purposes, in our context, the term 'spontaneous stress (insufficiency) fracture' looks apt and should have been used in all such reports.

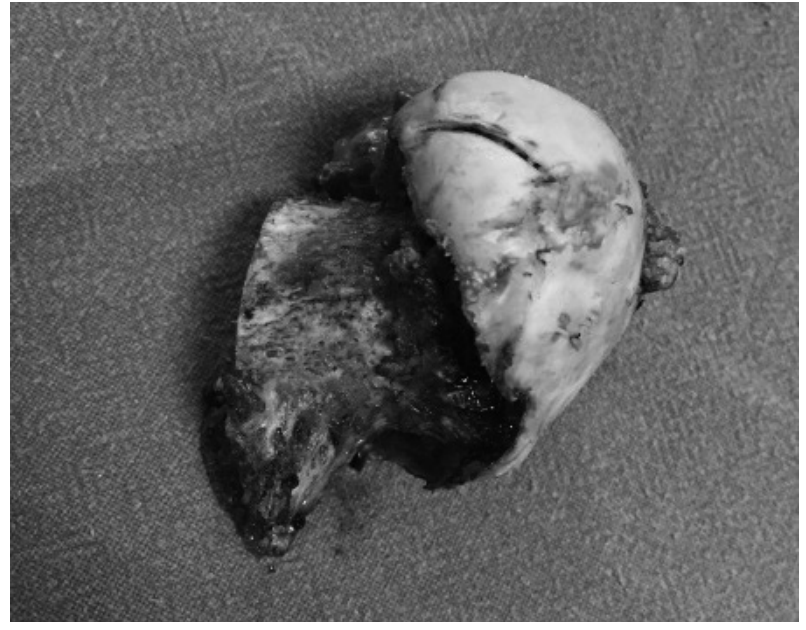

Figure 7. - Surgical specimen of femoral head resected during THA of the left side showing SSF as the plane between head and neck looks displaced.

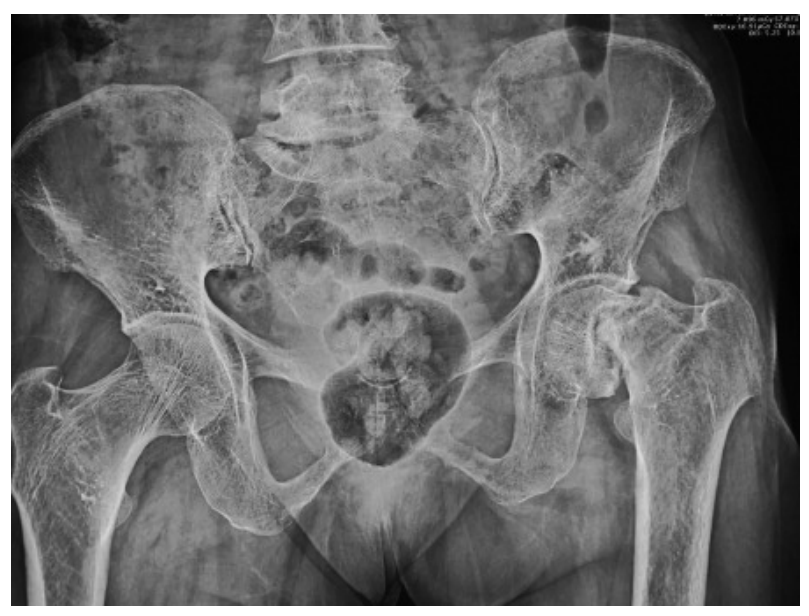

Figure 8. - Antero-posterior radiograph of pelvis with both hips of 54-years-old female showing ONFH on the left side (modified Ficat and Arlet stage II) with SSF.

Regarding fracture line propagation : Kenzora and Glimcher (20) proposed a hypothesis to explain the propagation of subcapital fracture in ONFH in 2 directions. They attributed this phenomenon to the focal resorption of subchondral bone while repair process is going on. One of the described directions was through a subchondral fracture in the necrotic area and the other was through the junction between the necrotic bone and the zone of repair owing to differences in the modulus of elasticity of necrotic and reparative bone. Cyclic loads generated by routine activities were considered responsible for 
Table II. - A comprehensive review of published cases of ONFH with superimposed SSF

(only 1 case described by Chang et al [11] had history of excessive marching in military training)

\begin{tabular}{|c|c|c|c|c|c|c|c|}
\hline $\begin{array}{l}\text { S. } \\
\text { no. }\end{array}$ & $\begin{array}{c}\text { Author/Year } \\
\text { of publication }\end{array}$ & $\begin{array}{c}\text { Country of } \\
\text { origin }\end{array}$ & $\begin{array}{l}\text { Number of cases } \\
\text { reported and } \\
\text { gender }\end{array}$ & Age in years & $\begin{array}{c}\text { ONFH: } \\
\text { Unilateral (U/L) or } \\
\text { Bilateral }(B / L)\end{array}$ & $\begin{array}{l}\text { Neck femur fracture: } \\
\text { Unilateral (U/L) or } \\
\text { Bilateral (B/L) }\end{array}$ & $\begin{array}{l}\text { Duration from onset of } \\
\text { symptoms to fracture }\end{array}$ \\
\hline 1 & $\begin{array}{l}\text { Usui et al [3] } \\
\quad(1996)\end{array}$ & Japan & $\begin{array}{l}4 \text { Females (in } 20 \\
\text { years study period) }\end{array}$ & $42,38,30,61$ & $\begin{array}{l}\text { The status of other hip } \\
\text { was not mentioned }\end{array}$ & $\mathrm{U} / \mathrm{L}$ in all cases & $\begin{array}{c}6 \text { months } \\
19 \text { months } \\
8 \text { months } \\
8 \text { months (had fall) } \\
\end{array}$ \\
\hline 2 & $\begin{array}{c}\text { Kim and Kim } \\
{[4]} \\
(2000)\end{array}$ & Korea & 2 Males & 58,60 & $\mathrm{~B} / \mathrm{L}$ in both the cases & $\mathrm{U} / \mathrm{L}$ in both the cases & $\begin{array}{l}2 \text { months } \\
1 \text { month }\end{array}$ \\
\hline 3 & $\begin{array}{l}\text { Min et al [5] } \\
\quad(2001)\end{array}$ & South Korea & $\begin{array}{c}9 \text { Males } \\
1 \text { Female (in } 5 \\
\text { years study period) }\end{array}$ & $\begin{array}{l}47,56,57,47,53 \\
42,36,55,58,68\end{array}$ & $\mathrm{~B} / \mathrm{L}$ in all cases & $\mathrm{U} / \mathrm{L}$ in all the cases & 1 month to 28 months \\
\hline 4 & $\begin{array}{c}\text { Loddenkemper } \\
\text { et al [6] } \\
(2002)\end{array}$ & Germany & 1 Female & 47 & $\begin{array}{l}\text { The status of other hip } \\
\text { was not mentioned }\end{array}$ & $\mathrm{U} / \mathrm{L}$ & Presented with neck of femur \\
\hline 5 & $\begin{array}{l}\text { Yoon et al [7] } \\
\quad(2004)\end{array}$ & Korea & 1 Male & 45 & $\begin{array}{l}\text { The status of other hip } \\
\text { was not mentioned }\end{array}$ & $\mathrm{U} / \mathrm{L}$ & 3 months \\
\hline 6 & $\begin{array}{l}\text { Kamiya et } \\
\text { al [8] } \\
(2004)\end{array}$ & Japan & 1 Female & 60 & $\mathrm{~B} / \mathrm{L}$ & $\mathrm{B} / \mathrm{L}$ simultaneous & 22 days \\
\hline 7 & $\begin{array}{c}\text { Lee and Suh } \\
{[9]} \\
(2005)\end{array}$ & $\begin{array}{l}\text { Republic of } \\
\text { Korea }\end{array}$ & 1 Male & 47 & $\begin{array}{c}\mathrm{B} / \mathrm{L} \\
\text { Right side- extensive } \\
\text { ONFH, } \\
\text { Left side- focal ONFH } \\
\end{array}$ & $\mathrm{B} / \mathrm{L}$ at different times & $\begin{array}{l}5 \text { months Rt } \\
11 \text { months Lt }\end{array}$ \\
\hline 8 & $\begin{array}{l}\text { Zuckerman et } \\
\text { al [10] } \\
(2006)\end{array}$ & USA & 1 Female & 46 & $\mathrm{~B} / \mathrm{L}$ & $\mathrm{B} / \mathrm{L}$ simultaneous & 6 months \\
\hline 9 & $\begin{array}{c}\text { Chang et al } \\
{[11]} \\
(2010)\end{array}$ & $\begin{array}{l}\text { Republic of } \\
\text { Korea }\end{array}$ & 1 Male & 23 & $\mathrm{U} / \mathrm{L}$ & $\begin{array}{l}\mathrm{B} / \mathrm{L} \text { simultaneous (both } \\
\text { were incomplete fatigue } \\
\text { stress fractures on medial } \\
\text { side only) }\end{array}$ & 3 months \\
\hline 10 & $\begin{array}{l}\text { Tompkins et } \\
\text { al [12] } \\
(2010)\end{array}$ & USA & $\begin{array}{c}1 \text { Male } \\
2 \text { Females } \\
\text { (in } 10 \text { years study } \\
\text { period) }\end{array}$ & $48,54,43$ & $\begin{array}{l}\mathrm{U} / \mathrm{L} 2 \\
\mathrm{~B} / \mathrm{L} 1\end{array}$ & $\mathrm{U} / \mathrm{L}$ in all the cases & $\begin{array}{l}10 \text { months } \\
15 \text { months } \\
4 \text { months }\end{array}$ \\
\hline 11 & $\begin{array}{l}\text { Vaishya [13] } \\
\quad(2012)\end{array}$ & $\begin{array}{l}\text { India (patient } \\
\text { was Iraqi) }\end{array}$ & 1 Male & 47 & $\mathrm{U} / \mathrm{L}$ & $\mathrm{U} / \mathrm{L}$ & 7 months \\
\hline 12 & $\begin{array}{c}\text { Fukui et al } \\
{[14]} \\
(2015)\end{array}$ & Japan & 1 Male & 60 & $\mathrm{U} / \mathrm{L}$ & $\mathrm{U} / \mathrm{L}$ & $\begin{array}{l}\text { Presented with neck femur } \\
\text { fracture }\end{array}$ \\
\hline 13 & $\begin{array}{c}\text { Kumar et al } \\
{[15]} \\
(2016)\end{array}$ & India & 1 Male & 42 & $\mathrm{U} / \mathrm{L}$ & $\mathrm{U} / \mathrm{L}$ & 18 months \\
\hline 14 & Present study & India & $\begin{array}{l}9 \text { Males } \\
1 \text { Female }\end{array}$ & $\begin{array}{l}28,54,32,32,31 \\
24,37,61,38,30\end{array}$ & $\begin{array}{l}\mathrm{U} / \mathrm{L} \text { (8 patients) } \\
\mathrm{B} / \mathrm{L} \text { (2 patients) }\end{array}$ & $\begin{array}{l}\text { U/L (8 patients) } \\
\text { B/L (2 patients) }\end{array}$ & 5 months to 59 months \\
\hline
\end{tabular}


Table II. - A comprehensive review of published cases of ONFH with superimposed SSF (only 1 case described by Chang et al [11] had history of excessive marching in military training)

\begin{tabular}{|c|c|c|c|c|c|}
\hline Etiology/ risk factor & $\begin{array}{l}\text { Investigations } \\
\text { performed }\end{array}$ & $\begin{array}{l}\text { Staging/ classification as } \\
\text { given by original author }\end{array}$ & $\begin{array}{c}\text { Authors' } \\
\text { interpretation as per } \\
\text { modified Ficat \& } \\
\text { Arlet staging }\end{array}$ & Treatment & Comments \\
\hline $\begin{array}{l}\text { Steroid use in all (for SLE } \\
\text { in } 3 \text { patients and for ITP in } \\
1 \text { patient) }\end{array}$ & $\begin{array}{l}\text { Radiographs, } \\
\text { Histopathology }\end{array}$ & None & $\begin{array}{c}\text { Unclassifiable } \\
\text { (published } \\
\text { radiographs of poor } \\
\text { quality) }\end{array}$ & $\begin{array}{l}\text { Femoral head } \\
\text { Replacement }\end{array}$ & $\begin{array}{l}\text { Classified neck femur fractures } \\
\text { following avascular necrosis into } \\
\text { two types }\end{array}$ \\
\hline $\begin{array}{l}\text { In 1st patient: excess } \\
\text { alcohol consumption, } 2^{\text {nd }} \\
\text { patient: steroid use (for } \\
\text { aplastic anemia) }\end{array}$ & $\begin{array}{l}\text { Radiographs, MRI, } \\
\text { Bone Scintigraphy }\end{array}$ & None & Stage 1 & $\begin{array}{l}\text { Bipolar Hemiarthro- } \\
\text { plasty }\end{array}$ & $\begin{array}{l}\text { ONFH should be considered } \\
\text { as a predisposing condition } \\
\text { for pathological femoral neck } \\
\text { fracture }\end{array}$ \\
\hline $\begin{array}{c}\text { Alcohol consumption in } 8 \\
\text { patients, and rest } 2 \text { were } \\
\text { idiopathic }\end{array}$ & $\begin{array}{l}\text { Radiographs, MRI, } \\
\text { Histopathology }\end{array}$ & $\begin{array}{c}\text { ARCO staging (two patients } \\
\text { in stage III, seven patients in } \\
\text { stage II, and one patient in } \\
\text { stage I) [21] }\end{array}$ & $\begin{array}{l}\text { X-rays published } \\
\text { for } 2 \text { patients only- } \\
\text { stage III }\end{array}$ & $\begin{array}{c}\text { Total Hip Arthroplasty } \\
\text { (THA) }\end{array}$ & $\begin{array}{l}\text { Osteosynthesis rarely should be } \\
\text { considered }\end{array}$ \\
\hline $\begin{array}{c}\text { Steroid use (for mixed } \\
\text { connective tissue disease } \\
\text { with progressive vasculitis) }\end{array}$ & $\begin{array}{l}\text { Radiographs, Bone } \\
\text { mineral densitometry }\end{array}$ & Ficat stage IV & Stage IV & THA & $\begin{array}{l}\text { Osteonecrosis and osteoporosis } \\
\text { with a fracture in the same } \\
\text { area as the side effects of } \\
\text { glucocorticoid treatment is } \\
\text { extremely rare }\end{array}$ \\
\hline-- & $\begin{array}{l}\text { Radiographs, MRI, } \\
\text { Pinhole scintigraphy, } \\
\text { Histopathology }\end{array}$ & $\begin{array}{c}\text { Type } 4 \text { according to Wu et } \\
\text { al MRI based classification } \\
{[22]}\end{array}$ & Stage II & $\begin{array}{l}\text { Tensor fascia lata } \\
\text { muscle pedicle bone } \\
\text { grafting without } \\
\text { internal fixation }\end{array}$ & $\begin{array}{l}\text { If diagnosis of the stress } \\
\text { fracture of the femoral neck is } \\
\text { questionable by radiography and } \\
\text { MRI, pinhole bone scintigraphy } \\
\text { is recommended }\end{array}$ \\
\hline $\begin{array}{l}\text { Steroids (for Sjögren } \\
\text { syndrome) }\end{array}$ & $\begin{array}{l}\text { Radiographs, MRI, } \\
\text { Bone mineral } \\
\text { densitometry, } \\
\text { Histopathology }\end{array}$ & $\begin{array}{l}\text { Garden [23] type IV Lt } \\
\text { Garden type III Rt }\end{array}$ & $\begin{array}{l}\text { Stage II on both the } \\
\text { sides }\end{array}$ & $\begin{array}{l}\text { Bipolar hemiarthro- } \\
\text { plasty on both the } \\
\text { sides }\end{array}$ & $\begin{array}{l}\text { Patients with ONFH whose } \\
\text { bone density is reduced needs } \\
\text { careful medical attention to avoid } \\
\text { atraumatic neck femur fractures }\end{array}$ \\
\hline Alcohol consumption & $\begin{array}{l}\text { Radiographs, MRI, } \\
\text { Bone Scintigraphy }\end{array}$ & None & $\begin{array}{l}\text { Stage IV (right) } \\
\text { Stage I (left) }\end{array}$ & $\begin{array}{l}\text { THA (right side) } \\
\text { In-situ pinning (left } \\
\text { side) }\end{array}$ & $\begin{array}{l}\text { Stress fracture of the } \\
\text { contralateral femoral neck } \\
\text { was caused by the incremental } \\
\text { repetitive mechanical loading }\end{array}$ \\
\hline $\begin{array}{l}\text { Steroids (for Interstitial } \\
\text { nephritis) } \\
\text { Alcohol }\end{array}$ & $\begin{array}{c}\text { Radiographs, Bone } \\
\text { mineral densitometry, } \\
\text { MRI }\end{array}$ & $\begin{array}{c}\text { International Classification } \\
\text { of Osteonecrosis of the } \\
\text { Femoral Head [24]: Stage } 1 \\
\text { bilateral }\end{array}$ & Stage I & $\begin{array}{l}\text { Sliding hip screws on } \\
\text { both the sides }\end{array}$ & $\begin{array}{c}\text { Placement of the sliding hip } \\
\text { screw more closely approximated } \\
\text { the technique of core } \\
\text { decompression than multiple lag } \\
\text { screws }\end{array}$ \\
\hline $\begin{array}{l}\text { Excessive marching in } \\
\text { military training }\end{array}$ & $\begin{array}{l}\text { Radiographs, } \\
\text { MRI, CT scan, } \\
\text { Bone scintigraphy, } \\
\text { Histopathology }\end{array}$ & ARCO stage 3 [22] & Stage II & \begin{tabular}{|c|}
$\mathrm{U} / \mathrm{L}$ Core \\
Decompression and \\
autograft mixed with \\
demineralized bone \\
matrix (proximally) \\
and allograft (distally) \\
\end{tabular} & $\begin{array}{l}\text { A femoral head preserving } \\
\text { procedure is recommended for } \\
\text { young patients. }\end{array}$ \\
\hline $\begin{array}{l}\text { HIV on antiretroviral } \\
\text { therapy (all } 3 \text { patients) } \\
\text { Steroids ( } 1 \text { patient) }\end{array}$ & Radiographs & None & $\begin{array}{l}\text { Stage IV ( } 2 \text { patients }) \\
\text { Stage III (1 patient) }\end{array}$ & $\begin{array}{l}\text { THA (2 patients) } \\
\text { THA after failed } \\
\text { osteosynthesis with } \\
\text { multiple screws ( } 1 \\
\text { patient) }\end{array}$ & $\begin{array}{l}\text { Its generally a mistake to attempt } \\
\text { osteosynthesis in this setting }\end{array}$ \\
\hline Sickle cell disease & $\begin{array}{l}\text { Radiographs, CT scan } \\
\text { (though published } \\
\text { image is misleading), } \\
\text { Histopathology }\end{array}$ & None & Stage IV & THA & $\begin{array}{l}\text { Femoral neck fracture due to } \\
\text { osteoporosis and medullary } \\
\text { infarcts }\end{array}$ \\
\hline $\begin{array}{c}\text { Steroids (for } \\
\text { dermatomyositis) }\end{array}$ & $\begin{array}{c}\text { Radiographs, Bone } \\
\text { densitometry, MRI, } \\
\text { Bone Scintigraphy, } \\
\text { Histopathology } \\
\end{array}$ & None & Stage I & $\begin{array}{c}\text { Bipolar } \\
\text { Hemiarthroplasty }\end{array}$ & $\begin{array}{l}\text { Osteonecrosis should be included } \\
\text { in the differential diagnosis of } \\
\text { insufficiency fracture of the } \\
\text { femoral neck }\end{array}$ \\
\hline Alcoholic, Tobacco-chewer & $\begin{array}{l}\text { Radiographs, MRI, } \\
\text { Histopathology }\end{array}$ & None & Stage II & THA & $\begin{array}{c}\text { Author had difficulty in } \\
\text { classifying or staging the } \\
\text { avascular femoral head changes } \\
\text { because this presentation has } \\
\text { not been included in existing } \\
\text { classifications }\end{array}$ \\
\hline $\begin{array}{l}\text { Steroids ( } 7 \text { patients), } \\
\text { Alcohol ( } 3 \text { patients), } \\
\text { Idiopathic ( } 3 \text { patients) }\end{array}$ & $\begin{array}{l}\text { Radiographs, MRI, } \\
\text { NCCT, Histopathology }\end{array}$ & $\begin{array}{c}\text { Modified Ficat and Arlet } \\
\text { stage II ( } 1 \text { patient), stage } \\
\text { III (3 patients), stage IV ( } 6 \\
\text { patients) }\end{array}$ & -do- & THA in all the cases & $\begin{array}{l}\text { Corticosteroids induced ONFH } \\
\text { has a propensity to develop SSF. } \\
\text { This entity should find a place in } \\
\text { existing classification system. }\end{array}$ \\
\hline
\end{tabular}


propagation of micro-factures into obvious fracture line. Whereas, Kim and Kim (4) and Min et al (5) suggested that extensive ONFH is pre-requisite for SSF to happen. Usui et al (3) proposed schematic illustration of propagation of SSF in ONFH, which in the authors' opinion, seems more plausible explanation. They too suggested 2 types of fracture line propagation. First was the conversion of microfracture at junctional area (subcapital zone) between necrotic and repairing bone into complete one. The other was initiation of the fracture line between the superior portion of the head and neck where loading or torsion can extend the fracture line to inferior cortex of the femoral neck. This description well explains the diversity of the time lag between exaggeration of hip pain to presentation as the patients belonging to second type are likely to present early.

Description: ONFH presenting with SSF is being recognised as a separate entity, though the presentation remains rare. Thorough literature search yielded 23 such reports, 13 in English language (Table II) (3-15,21-24), 8 in Japanese, and one each in Dutch and French. The reports other than English language based medical literature were excluded from the review. Interestingly, sudden increase in clinical symptoms without antecedent history of trauma has been observed to be a common denominator in the reported cases of SSF complicating ONFH so far. Chang et al described this phenomenon after repetitive stress in military training (11). Unilateral SSF was described in majority of the reports except in 3 patients where this unusual presentation was noticed on both the sides (8-10).

Various pre-existing conditions or risk factors have been described to be associated with ONFH that eventually resulted in SSF. Corticosteroid use has been associated in 10 out of 28 reported patients $(3,4,6,8,10,12,14)$. It is evident that these steroid prescriptions were medically indicated in all these reports. Authors have observed that indiscriminate use of oral and injectable steroids is rampant in Indian youths for the want of improving appetite and gaining muscle mass. This probably explains the early age of presentation in our patients mean age 37.1 years (range : 24 years to 61 years) $\}$ in

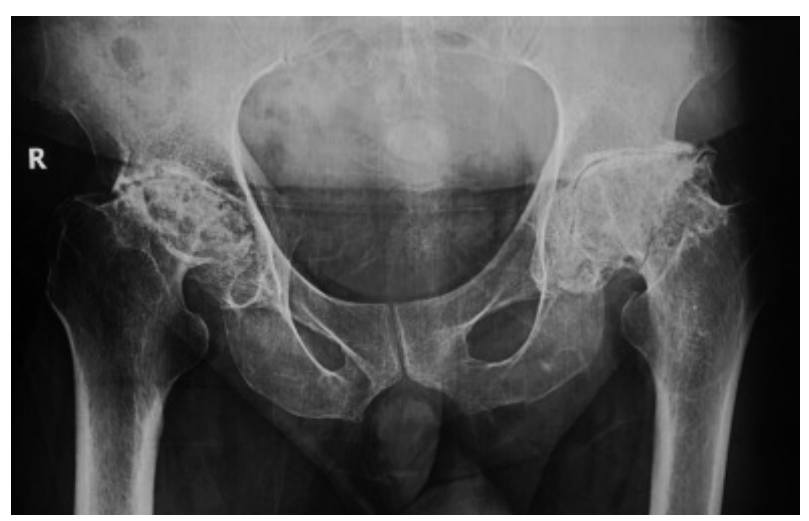

Figure 9. - Antero-posterior radiograph of pelvis with both hips of 31-years-old male showing ONFH on both the sides (modified Ficat and Arlet stage IV) with SSF on the left side.

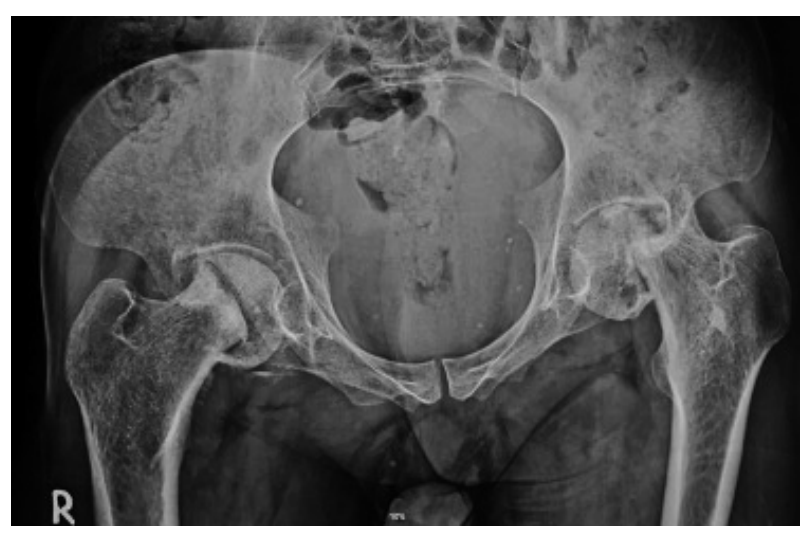

Figure 10. - Antero-posterior radiograph of pelvis with both hips 61-years-old male showing bilateral ONFH (modified Ficat and Arlet stage IV) with bilateral SSF.

sharp contrast to other reports (mean age 48.93 years (range : 23 years to 68 years) $\}$. Apart from this, other reported etiological factors were: excessive alcohol consumption (12 patients), HIV on retroviral therapy (3 patients), and sickle cell anemia (1 patient).

SSF has been reported to occur with femoral head in varying degrees of osteonecrosis (Table II). It has been suggested that ONFH should be one of the differentials for insufficiency fractures of the femoral neck $(4,14)$. Few reports have reported SSF to be the first sign of ONFH $(3,4)$. However, our observation has been quite different as all the patients (except one) in our series presented in Ficat and Arlet stage III and IV. This probably is due to 
the patients' attitude of presenting late in advanced stage of disease in Indian subcontinent.

All the reported patients (including ours) were treated with THA except for: (1) Bipolar hemiarthroplasty in 4 patients (5 hips) $(4,8,14) ;(2)$ Osteosynthesis in 3 patients (4 hips) : sliding hip screw in 1 patient (2 hips) (10) and multiple lag screws fixation in 2 patients (2 hips) $(9,12)$; and (3) Core decompression with impaction grafting in 1 patient (1 hip) (11). Tompkins et al made a failed attempt to achieve osteosynthesis with percutaneous pinning in HIV positive patient (12). Chang et al performed core decompression with grafting with success for incomplete fracture line (11). Yoon et al performed staged core decompression/ biopsy and tensor fascia late muscle-pedicle bone graft, but unfortunately patient died of cardiac problems 6 months later (7). Being a rare entity, standard treatment guidelines are not available for such clinical presentation. The authors feel that THA should be the preferred modality of treatment and osteosynthesis may be performed, though with caution, for early-stage disease with undisplaced/ incomplete fracture in young individuals.

Regarding inclusion of this entity in the existing classification system: There are many classifications/ staging systems used for ONFH which are based on radiographs, MRI and bone scan (2,21,22,24-27). Modified Ficat and Arlet is the most commonly preferred and widely used classification system (2). To the authors' surprise, none of the existing classification systems seems to include SSF in their description. Taken together, the reports on the initiation and propagation of fracture lines in spontaneous fracture in ONFH as discussed above, it appears that much breath has been invested into a largely inconsequential cause. Authors believe that development of SSF in ONFH is no more than a natural continuum of events wherein a chance convergence of forces can cause fragmentation of the necrotic bone or separation of the dead bone from the living through 'fault lines' so brilliantly theorized by various workers. Given the evidence reported in the literature (including ours) on SSF in ONFH, two observations stand out clearly. One, SSF occurs primarily in modified Ficat and Arlet stage III or IV of ONFH. Two, the current standard of care is THA for these stages. Occurrence of spontaneous fractures neither alters the recommendation of THA nor does it alter the outcome of surgery, per se. Having said this, however, authors do see the merit in sensitization of practicing orthopaedic surgeons that development of SSF in ONFH can brook no delay in the definitive management of the entity. On the one hand, the patient will report to the facility early because of sudden increase in pain; on the other hand, the surgeon will also have to prioritize the surgery. To this end, the talk of SSF finding a place in the classification of ONFH appears justified. The authors recommend for a provision of separate subclass in the existing classification systems to accommodate this clinical presentation. For example, Ficat and Arlet stage I/ II/ III/ IV should be read as If/ IIf/ IIIf/ IVf in the event of superimposed SSF.

\section{REFERENCES}

1. Lieberman JR, Berry DJ, Mont MA, Aaron RK, Callaghan JJ, Rayadhyaksha A, Urbaniak JR. Osteonecrosis of the hip : management in the twenty-first century. J. Bone Joint Surg. Am. 2002 ; 84(5) : 834-853.

2. Ficat RP. Idiopathic bone necrosis of the femoral head. Early diagnosis and treatment. J. Bone Joint Surg. Br. $1985 ; 67: 3-9$.

3. Usui M, Inoue H, Yukihiro S, Abe N. Femoral neck fracture following avascular necrosis of the femoral head. Acta Med. Okayama. 1996 ; 50(2) : 111-117.

4. Kim Y-M, Kim HJ. Pathological fracture of the femoral neck as the first manifestation of osteonecrosis of the femoral head. J. Orthop. Sci. 2000 ; 5(6) : 605-609.

5. Min BW, Koo K-H, Song H-R, Cho S-H, Kim S-Y, Kim Y-M, Kang C-S. Subcapital fractures associated with extensive osteonecrosis of the femoral head. Clin. Orthop. Relat. Res. 2001 ; 390 : 227-231.

6. Loddenkemper K, Perka C, Burmester G-R, Buttgereit F. Coincidence of asymptomatic avascular necrosis and fracture of the femoral neck : a rare combination of glucocorticoid induced side effects. Ann. Rheum. Dis. 2002 ; 61(7) : 665-666.

7. Yoon TR, Rowe SM, Song EK, Mulyadi D. Unusual osteonecrosis of the femoral head misdiagnosed as stress fracture. J. Orthop. Trauma. $2004 ; 18: 43-47$.

8. Kamiya M, Ueno M, Yamaguchi H, Kanata S, Sohen S. Sjögren's syndrome with bilateral spontaneous fracture of the femoral neck following aseptic necrosis of the femoral head. Mod. Rheumatol. 2004 ; 14 : 494-497.

9. Lee JS, Suh KT. A pathological fracture of the femoral neck associated with osteonecrosis of the femoral head 
and a stress fracture of the contralateral femoral neck. $J$. Arthroplasty. $2005 ; 20(6)$ : 807-810.

10. Zuckerman JD, Shin SS, Polatsch DB, Schweitzer M. Concurrent bilateral femoral neck stress fractures and osteonecrosis of the hip. J. Bone Joint Surg. Am. 2006 ; 88(4) : 857-860.

11. Chang J-D, Yoo J-H, Agashe AS, Cho S-H. Concurrent bilateral femoral neck stress fractures and unilateral osteonecrosis of the hip : a case report. Current Orthop. Pract. 2010 ; 21(3) : E13-E16.

12. Tompkins M, Mkandawire NC, Harrison J. Subcapital femoral neck fracture in patients with HIV and osteonecrosis of the femoral head. SA Orthop. J. $2010 ; 9(4): 49-53$.

13. Vaishya R. Spontaneous fracture of the femoral neck in preexisting avascular necrosis of femoral head in sickle cell disease. Chin. J. Traumatol. $2012 ; 15(5): 312-314$.

14. Fukui K, Kaneuji A, Matsumoto T. Occult fracture of the femoral neck associated with extensive osteonecrosis of the femoral head : A case report. Int. J. Surg. Case Rep. 2015 ; $14: 136-140$.

15. Kumar V, Narendran P, Kumar D, Walia R. Avascular necrosis of femoral head presenting as pathological subcapital neck of femur fracture: An unclassified presentation. Int. J. Orthop. Sci. 2016 ; 2(4) : 230-232.

16. Harris WH. Traumatic arthritis of the hip after dislocation and acetabular fractures: treatment by mold arthroplasty. An end-result study using a new method of result evaluation. J. Bone Joint Surg. Am. 1969 ; 51(4) : 737-755.

17. Marchetti P, Binazzi R, Vaccari V, Girolami M, Morici F, Impallomeni $\mathbf{C}$, et al. Long-term results with cementless Fitek (or Fitmore) cups. J. Arthroplasty. 2005 ; 20(6) : 730737.
18. Pentecost RL, Murray RA, Brindley HH. Fatigue, insufficiency, and pathologic fractures. JAMA. $1964 ; 187(13)$ : 1001-1004.

19. Daffner RH. Stress fractures : current concepts. Skeletal Radiol. $1978 ; 2$ : 221-229.

20. Kenzora JE, Glimcher MJ. Pathogenesis of idiopathic osteonecrosis : the ubiquitous crescent sign. Orthop. Clin. North Am. 1985 ; 16(4) : 681-696.

21. ARCO (Association Research Circulation Osseous). Committee on terminology and classification. ARCO News. $1992 ; 4: 41-46$.

22. Wu Z, Yan X, Liu Z, Pan S, Cao X. Avascular necrosis of the femoral head: MR imaging with radiological and histological correlation. Chin. Med. J. (Engl).1998; 111(7) : 599-602.

23. Garden RS. Low-angle fixation in fractures of the femoral neck. J. Bone Joint Surg. Br. 1961 ; 43 : 647-663.

24. Mont MA, Hungerford DS. Non-traumatic avascular necrosis of the femoral head. J. Bone Joint Surg. Am. 1995 ; 77(3) : 459-474.

25. Steinberg ME, Hayken GD, Steinberg DR. A quantitative system for staging avascular necrosis. J. Bone Joint Surg. Br. 1995 ; 77(1) : 34-41.

26. Marcus ND, Enneking WF, Massam RF. The silent hip in idiopathic aseptic necrosis. Treatment by bone-grafting. $J$. Bone Joint Surg. Am. 1973 ; 55(7) : 1351-1366.

27. Ohzono K, Saito M, Sugano N, Takaoka K, Ono K. The fate of nontraumatic avascular necrosis of the femoral head. A radiologic classification to formulate prognosis. Clin. Orthop. Relat. Res. $1992 ; 277$ : 73-78. 